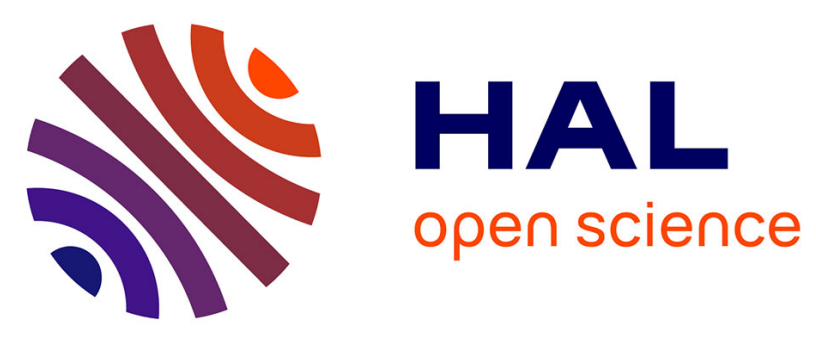

\title{
Ni-coated graphite felt modified with Ag nanoparticles: \\ A new electrode material for electro-reductive dechlorination
}

\author{
Y.-Y. Lou, W. He, E. Verlato, M. Musiani, D. Floner, F. Fourcade, A. \\ Amrane, C. Li, Z.-Q. Tian, O. Merdrignac-Conanec, et al.
}

\section{To cite this version:}

Y.-Y. Lou, W. He, E. Verlato, M. Musiani, D. Floner, et al.. Ni-coated graphite felt modified with Ag nanoparticles: A new electrode material for electro-reductive dechlorination. Journal of Electroanalytical Chemistry, 2019, 849, pp.113357. 10.1016/j.jelechem.2019.113357 . hal-02281676

\section{HAL Id: hal-02281676 \\ https://hal-univ-rennes1.archives-ouvertes.fr/hal-02281676}

Submitted on 26 Nov 2020

HAL is a multi-disciplinary open access archive for the deposit and dissemination of scientific research documents, whether they are published or not. The documents may come from teaching and research institutions in France or abroad, or from public or private research centers.
L'archive ouverte pluridisciplinaire HAL, est destinée au dépôt et à la diffusion de documents scientifiques de niveau recherche, publiés ou non, émanant des établissements d'enseignement et de recherche français ou étrangers, des laboratoires publics ou privés. 
Ni-coated graphite felt modified with Ag nanoparticles: a new electrode material for electro-reductive dechlorination

Yao-Yin Lou ${ }^{\mathrm{a}, \mathrm{b}^{\dagger}}$, Wenyan $\mathrm{He}^{\mathrm{a}, \mathrm{b}^{\dagger}}$, Enrico Verlato ${ }^{\mathrm{c}}$, Marco Musiani ${ }^{\mathrm{c}}$, Didier Floner ${ }^{\mathrm{a}}$, Florence Fourcade ${ }^{\mathrm{a}}$, Abdeltif Amrane ${ }^{\mathrm{a}}$, Chaoyu Li ${ }^{\mathrm{d}}$, Zhong-Qun Tian ${ }^{\mathrm{d}}$, Odile Merdrignac-Conanec ${ }^{\mathrm{a}}$, Nathalie Coulon ${ }^{\mathrm{e}}$, Florence Geneste $\mathrm{a}^{\mathrm{a}}$

a) Univ Rennes, CNRS, ISCR-UMR 6226, F-35000 Rennes, France

b) Univ Rennes, Ecole Nationale Supérieure de Chimie de Rennes, CNRS, ISCR-UMR 6226, F-35000 Rennes, France

c) ICMATE CNR - Corso Stati Uniti 4 - 35127 Padova, Italy

d) State Key Laboratory for Physical Chemistry of Solid Surfaces, MOE Key Laboratory of Spectrochemical Analysis and Instrumentation, College of Chemistry and Chemical Engineering, iChEM, Xiamen University, Xiamen 361005, China

e) Université de Rennes 1, IETR, UMR-CNRS 6164, Campus de Beaulieu, 35042, Rennes cedex, France

\section{Abstract}

Reductive removal of the organochlorine herbicide alachlor on Ni-coated graphite felt modified with Ag nanoparticles (Ag/Ni@GF) was studied. Ag/Ni@GF was prepared by spontaneous deposition of silver onto Ni-coated graphite felt (Ni@GF), which was previously obtained by electrodeposition of $\mathrm{Ni}$ onto graphite felt (GF). Interestingly, Ag/Ni@GF exhibited a high specific surface area of $26 \mathrm{~m}^{2} \mathrm{~g}^{-1}$ determined by the Brunauer-Emmett-Teller

\footnotetext{
${ }^{*}$ Corresponding author at: Univ Rennes, CNRS, ISCR-UMR 6226, F-35000 Rennes, France E-mail address: florence.geneste@univ-rennes1.fr (F. Geneste)
} 
(BET) method and a high Ag loading of $13.7 \mathrm{mg} \mathrm{cm}^{-3}$ as shown by electrochemical analyses. Alachlor (50 mg $\mathrm{L}^{-1}$ in $0.05 \mathrm{M} \mathrm{NaOH}$ ) was successfully reduced at $-0.9 \mathrm{~V}$ vs. mercurymercurous sulfate electrode with $96 \%$ conversion efficiency and a current efficiency up to 33\%. The main by-product was its dechlorinated derivative, deschloroalachlor, obtained with 76\% yield. Surface-enhanced Raman scattering (SERS) showed that PVP, necessary to control Ag nanoparticles deposition, does not affect the catalytic activity of Ag. Ag/Ni@GF electrodes could be used several times, highlighting their good stability.

\section{Keywords}

Electrocatalytic reduction, organochlorine compound, Ag nanoparticle, graphite felt, alachlor

\section{Introduction}

Organochlorine compounds represent one of the most undesirable classes of contaminants, since they are biorecalcitrant and inevitably leave residues in the environment surrounding human activity. Many physico-chemical methods have been investigated to degrade them, including photocatalytic oxidation [1], Fenton oxidation [2], sonoelectrochemical oxidation [3] and electrochemical oxidation-reduction combined processes [4]. The main drawback of these methods is the generation of non-selective reactive radicals (e.g. $\cdot \mathrm{OH}$ and $\cdot \mathrm{O}_{2}$ in electroFenton or oxidation on BDD) that lead to uncontrolled by-products. Reductive dehalogenation processes, especially electroreduction have been proposed as very promising approaches for the removal of hazardous organic halides, since no extra toxic chemical is needed, a high selectivity is obtained and the whole process is performed under mild conditions [5]. Metallic electrodes such as $\mathrm{Ag}[6,7], \mathrm{Pd}[8], \mathrm{Cu}[9,10]$ and $\mathrm{Au}[11]$ have been reported as good catalysts for the cleavage of the $\mathrm{C}-\mathrm{X}$ bond $(\mathrm{X}=\mathrm{Cl}, \mathrm{Br}$, or I). For example, 2,4- 
dichlorophenoxyacetic acid has been reduced at Pd modified $\mathrm{Ni}$ foam with a removal efficiency of $98 \%$ and a maximal current efficiency of 14\% [12] and trichloroacetic acid was selectively reduced at $\mathrm{Cu}$, due to its strong adsorption on the electrode surface via $\mathrm{Cu}-\mathrm{Cl}$ and Cu-CO bonds, shown by SERS [13]. Silver is well known for its high catalytic activity toward the reduction of carbon-halogen bonds, due to its strong tendency to form Ag...X...R interactions with organic halides. For example, Rondinini et al. [14] found that $\mathrm{CHCl}_{3}$ is converted to $\mathrm{CH}_{4}$ at Ag nanoparticles modified-carbon powder with $100 \%$ current efficiency, and Ardizzone et al. [15] observed a remarkable 0.4-1.2 V shift in the positive direction at Ag with respect to glassy carbon, known as a non-catalytic electrode.

Nanoscale electrode materials can decrease the manufactural cost of the cathode, when dealing with a large volume of water, and can enhance the electrocatalytic performance by a high surface/volume ratio, compared to polycrystalline bulk counterparts [15]. Generally, there are two common ways to deposit Ag nanoparticles on the electrode support: electrodeposition and spontaneous deposition via galvanic displacement reactions. Although electrodeposition is a good method to control nanoparticle size and loading, it might lead to heterogeneous deposits, due to uneven current distribution in different areas of complex shape electrodes [16]. Spontaneous deposition, interesting for its simplicity and to produce large complex-shape electrodes [17], has been extensively used to prepare nanoparticle-modified $\mathrm{Ni}$ foam electrodes $[16,18,19]$. We have previously used a spontaneous deposition approach to achieve the preparation of Ag nanoparticle-modified Ni foam electrodes (Ag/Ni foam) and have shown their good catalytic properties for the electroreduction of a widely used chloroacetanilide herbicide, alachlor, known to contaminate ground and surface waters due to its biorecalcitrance [18].

In this work, we report the preparation of a new catalytic electrode material (Ag/Ni@GF) by spontaneous deposition of Ag onto Ni-coated graphite felt (Ni@GF). The use of Ni-coated 
graphite felt as support is particularly attractive owing to its high specific surface area compared with Ni foam, high electrical conductivity, good mechanical strength and low specific weight [20]. Moreover, it can be prepared in large scale at moderate cost (around 3.5

cents $\mathrm{cm}^{-3}$ ), which is suitable for environmental applications. Surface area and Ag loading of Ag/Ni@GF electrodes have been evaluated and their catalytic ability to reduce alachlor has been studied and compared to results previously obtained with a Ag/Ni foam electrode.

\section{Experimental Section}

\subsection{Chemical and materials}

$\mathrm{Ni}$ sulfate hexahydrate $\left(\mathrm{NiSO}_{4} \cdot 6 \mathrm{H}_{2} \mathrm{O}\right)$, anhydrous sodium sulfate $\left(\mathrm{Na}_{2} \mathrm{SO}_{4}\right) 99 \%$, sodium thiosulfate pentahydrate $\left(\mathrm{Na}_{2} \mathrm{~S}_{2} \mathrm{O}_{3} \cdot 5 \mathrm{H}_{2} \mathrm{O}\right)$, silver nitrate $\left(\mathrm{AgNO}_{3}\right)$, PVP (polyvinylpyrrolidone, molecular weight 10,000) were purchased from Alfa Aesar and boric acid 99\% was supplied by Acros Organics. Nitric acid was obtained from Sigma-Aldrich. Graphite felt (GF, Recycled vein graphite RVG 4000) was supplied by Mersen (France).

\subsection{Preparation of Ni coated-graphite felt modified with Ag nanoparticles (Ag/Ni@GF)}

Ag/Ni@GF was prepared by a two-step procedure presented in Fig. 1, including: (1) pulseelectrodeposition preparation of the Ni-coated GF (Ni@GF); (2) spontaneous deposition of Ag nanoparticles onto the Ni-coated GF by a galvanic replacement reaction in the presence of PVP, a capping agent used to control the shape and size of the Ag nanoparticles [17, 21]. Each step is described below. 


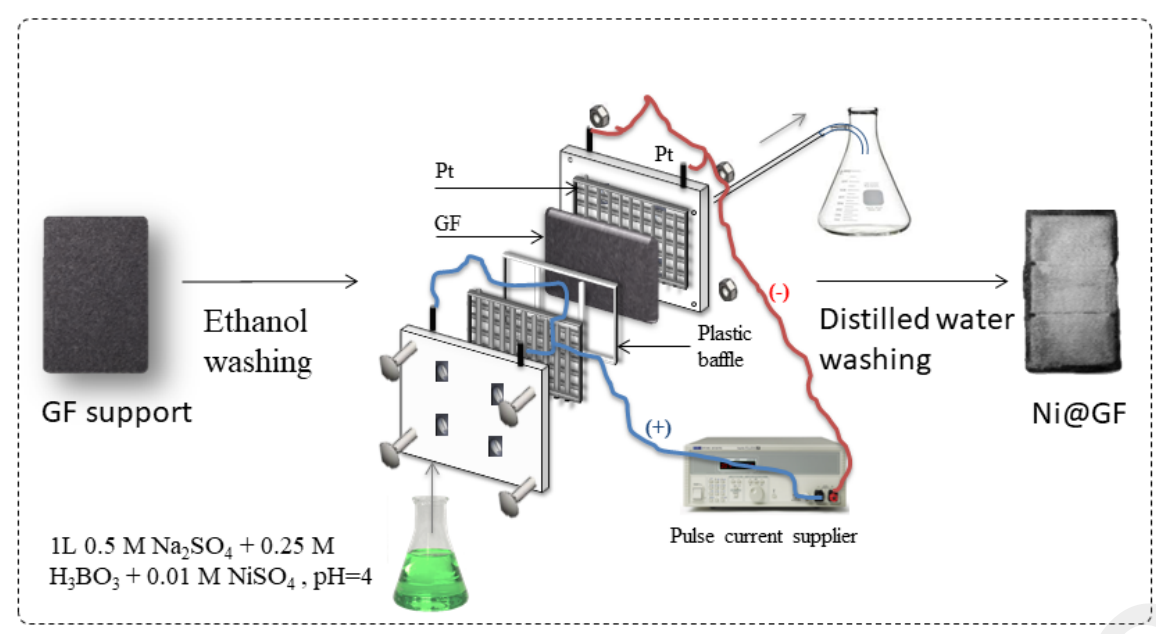

Preparation of Ni@GF

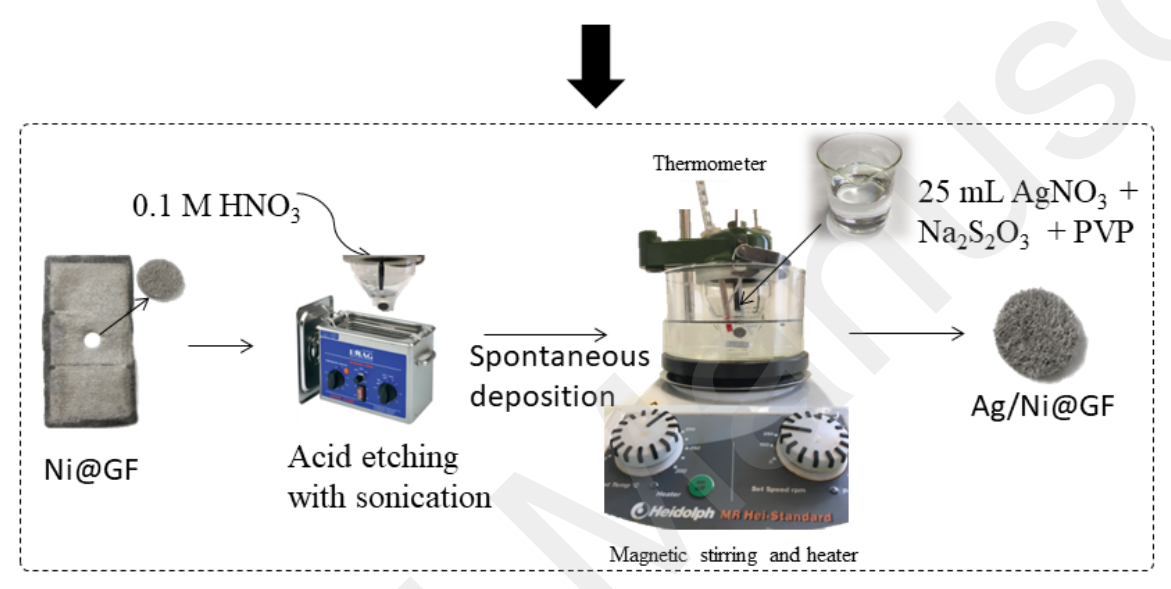

Spontaneous deposition of silver nanoparticles on Ni@GF

Fig. 1. Preparation of Ag/Ni@GF electrodes.

Electrodeposition of Ni on graphite felt. Ni@GF was obtained at room temperature, according to a previously reported protocol [20] modified as follows: 2 L of the electrolyte solution containing $0.5 \mathrm{M} \mathrm{Na}_{2} \mathrm{SO}_{4}, 0.25 \mathrm{M}$ boric acid and $0.01 \mathrm{M} \mathrm{NiSO}_{4} \cdot 6 \mathrm{H}_{2} \mathrm{O}$ was flowed through the GF at a rate of $8 \mathrm{~mL} \mathrm{~min}^{-1}$ in a home-made flow cell, shown in Fig. 1 . The GF $(10.7 \times 5.8$ $\times 0.3 \mathrm{~cm}$ ), used as the working electrode, was located between two platinum grid counterelectrodes to obtain a homogeneous potential distribution in the three-dimensional GF. Before electrodeposition, the GF was successively rinsed with pure methanol and water. During the electrodeposition process, the $\mathrm{pH}$ of the electrolyte solution was adjusted to 4 by adding 0.5 
$\mathrm{M} \mathrm{H}_{2} \mathrm{SO}_{4}$. A periodically changing current, with an on-pulse $\left(80 \mathrm{~mA} \mathrm{~cm}{ }^{-2}\right.$, referred to the geometric area of the felt) for $30 \mathrm{~s}$ and then an off-pulse ( $0 \mathrm{~A}$ ) for $30 \mathrm{~s}$, was applied by a Power Flex generator. The electrolyte solution (2 L) was flowed through the porous GF from one side to the other side (cycle 1) and then the direction was reversed (cycle 2). The flow rate was $8 \mathrm{~mL} \mathrm{~min}^{-1}$, so each cycle lasted 250min. After electrodeposition, the Ni@GF was carefully washed with distilled water to eliminate residual salts.

Spontaneous deposition of Ag nanoparticles onto Ni@GF. Deposition of Ag nanoparticles onto Ni@GF was carried out by a galvanic displacement reaction, Equation (1)

$\mathrm{Ni}+2 \mathrm{Ag}^{+} \rightarrow \mathrm{Ni}^{2+}+2 \mathrm{Ag}$

A previously reported method [17] was modified as follows. Ni@GF was etched in $0.1 \mathrm{M}$ $\mathrm{HNO}_{3}$ for $3 \mathrm{~min}$ and then rinsed with water three times for 5min; sonication was applied during both etching and rinsing. Ag deposition was carried out in a solution containing 1-10 $\mathrm{mM} \mathrm{AgNO} 3,8-80 \mathrm{mM} \mathrm{Na}_{2} \mathrm{~S}_{2} \mathrm{O}_{3} \cdot 5 \mathrm{H}_{2} \mathrm{O}$ and 0.1-0.2 mM PVP under stirring at open circuit. The solution was maintained under argon at $25 \pm 0.5{ }^{\circ} \mathrm{C}$. To estimate the Ag loading, an electrochemical method described in [18] was used. Ag and Ni present in the samples were exhaustively dissolved in a $5 \mathrm{M}$ solution of $\mathrm{HNO}_{3}$ at $80{ }^{\circ} \mathrm{C}$; then the limiting $\mathrm{Ag}^{+}$reduction current at a gold rotating disc electrode (2000 rpm) was measured and compared with a calibration curve. Determination of the concentration of $\mathrm{Ag}^{+}$by this method agreed within $5 \%$ with ICP-MS results [17].

\subsection{Flow electroreduction of alachlor}

The dechlorination reaction was performed in a home-made flow cell. To ensure a good homogeneity of the potential distribution in the three-dimensional working electrodes, Ni@GF and Ag/Ni@GF electrodes were located between two interconnected DSA counterelectrodes (dimensionally stable anodes, AC-2004, supplied by ECS International Electro 
Chemical Services, France) [22]. The compartments were separated by cationic exchange membranes (Nafion ${ }^{\mathrm{TM}} 417$ membrane, France). The reference electrode (mercury-mercurous sulfate - MSE) was positioned in the middle of the working electrode (10mm diameter and $1.7 \mathrm{~mm}$ thickness) and the potential (-0.9 to $-1.6 \mathrm{~V} / \mathrm{MSE})$ was applied by use of a VersaSTAT 3 potentiostat from Ametek/Princeton Applied (Elancourt, France). The solution (50 mg L $\mathrm{L}^{-1}$ of alachlor in $0.05 \mathrm{M} \mathrm{NaOH}$ ) percolated the porous electrode thanks to a Gilson minipuls 3 peristaltic pump (Middleton, WI, USA). The typical electrolysis duration was 100min. At predetermined time intervals, $200 \mu \mathrm{L}$ samples of solution were withdrawn from the cathode compartment for HPLC analysis. The conversion of alachlor was calculated as the molar ratio between the consumed alachlor and its initial amount. The yield of deschloroalachlor was determined as the molar ratio between formed deschloroalachlor and the initial amount of alachlor. The current efficiency (CE in \%) for the dechlorination reaction was calculated by use of Equation (2):

$C E=n F \frac{n_{\text {alachlor }}}{Q} \times 100$

where $n$ is the number of electrons $(n=2), F$ is the Faraday constant (96500 $\mathrm{C} \mathrm{mol}^{-1}$ ), $n_{\text {alachlor }}$ is the amount of consumed alachlor (mol), and $Q$ is the amount of charge consumed (C).

\subsection{Apparatus and analysis}

The surface morphology of electrode materials was analyzed by means of scanning electron microscopy (SEM), with a Jeol JSM 7100F (10kV) instrument, equipped with a field emission gun, operating in high-vacuum conditions, at an accelerating voltage variable from 2 to $20 \mathrm{keV}$, depending on the observation needs. The crystalline structure was analyzed with a Bruker D8 Advance X-ray diffractometer equipped with $\mathrm{Cu} \mathrm{K} \alpha_{1}$ radiation source $(\lambda=$ $0.15406 \mathrm{~nm}$ ) in the $\theta-2 \theta$ configuration. Nitrogen adsorption measurements were carried out with a Micromeritics ASAP 2010 instrument at 77K. Prior to adsorption, the electrode 
materials were out-gassed under vacuum at room temperature. Their surface area was calculated according to the Brunauer-Emmett-Teller (BET) method. Surface-enhanced Raman scattering (SERS) was performed with a XploRA Raman instrument Jobin Yvon-Horiba, France, equipped with an 50 X, NA 0.5 objective, that used a 532nm Laser line, with a 0.3 or $3.0 \mathrm{~mW}$ power at sample for as-prepared and used electrodes, respectively. The concentration of alachlor and deschloroalachlor were determined with a Waters 996 high performance liquid chromatography (HPLC) system equipped with a Waters 996 PDA (Photodiode Array Detector) and a Waters 600 LCD Pump. The separation was achieved on a Waters C-18 (5 $\mu \mathrm{m}$; $4.6 \times 250 \mathrm{~mm}$ ) reversed-phase and the mobile phase consisted of a mixture of acetonitrile/ultrapure water (70/30, v/v). The flow rate was $0.4 \mathrm{~mL} \mathrm{~min}^{-1}$ and $50 \mu \mathrm{L}$ injection was used. Detection was carried out at $195 \mathrm{~nm}$.

\section{Results and Discussion}

\subsection{Preparation of Ag/Ni@GF}

\subsubsection{Preparation of Ni@GF}

We previously reported a suitable electrodeposition method to homogeneously coat fibers of graphite felts with a Ni layer in a batch cell [20]. In this work, we report an optimized method that uses a flow electrochemical cell to enhance mass transport inside the felt (Fig. 1). A low $\mathrm{Ni}^{2+}$ concentration $(0.1 \mathrm{mM})$ and high current densities were also used to allow the electrodeposition to be limited by diffusion of ions from the bulk solution to the electrode surface. As shown in Figures S1(a) and S1(b), after four deposition cycles there were still some areas of the graphite felt not covered by $\mathrm{Ni}$, but after six cycles all fibers were covered by a continuous Ni layer. To check the homogeneity of the Ni coating, the Ni@GF was cut transversally and analyzed by SEM. A similar nickel film was found for the internal and external parts of the graphite felt. However, the thickness of the Ni coating varied from ca. 0.8 
$\mu \mathrm{m}$ in edge areas to ca. $0.19 \mu \mathrm{m}$ in center areas of Ni@GF (respectively named Ni@GF-edge and Ni@GF-center in Fig. S1). The thickness on the edge part of the felt was higher, probably due to the higher current density on the part of felt that was closer to the contact. The density of Ni@GF-center $\left(196 \pm 4 \mathrm{mg} \mathrm{cm}^{-3}\right)$ compared with the density of the graphite felt $(92.4 \pm 0.9$ $\mathrm{mg} \mathrm{cm}{ }^{-3}$ ) allows us to estimate a Ni loading of $104 \mathrm{mg} \mathrm{cm}^{-3}$, which is significantly lower than for Ni foam (220 $\left.\mathrm{mg} \mathrm{cm}^{-3}\right)$.

\subsubsection{Modification of Ni@GF with Ag nanoparticles}

Modification of Ni@GF with Ag nanoparticles was performed by use of thiosulfate solutions, as previously reported for the preparation of $\mathrm{Ag} / \mathrm{Ni}$ foam [18]. Preliminary tests carried out in the same concentrations ( $1 \mathrm{mM} \mathrm{AgNO}_{3}, 80 \mathrm{mM} \mathrm{Na}_{2} \mathrm{~S}_{2} \mathrm{O}_{3}$, and $0.2 \mathrm{mM} \mathrm{PVP}$ ) showed that the conditions previously used to modify the Ni foam with Ag nanoparticles were not directly adaptable to Ni@GF. Indeed, a low density of nanoparticles was obtained probably due to the high surface area of Ni@GF compared with Ni foam. Furthermore, the distribution of Ag nanoparticles was more homogeneous on Ni@GF-center than on Ni@GF-edge. Hence, Ni@GF-center with Ni thickness around $0.19 \mu \mathrm{m}$ was preferred for further deposition of Ag nanoparticles.

According to the literature [23-25], sonication can enhance the chemical activity of reacting sites and the mass transport of compounds to the electrode surface, resulting in an increased number of nucleation sites. Therefore, the influence of sonication on the deposition of Ag nanoparticles on Ni@GF was checked. As detailed in Table S1, experiments were carried out with two different solutions $\left(10 \mathrm{mM} \mathrm{AgNO}_{3}, 80 \mathrm{mM} \mathrm{Na}_{2} \mathrm{~S}_{2} \mathrm{O}_{3}\right.$ and $0.2 \mathrm{mM}$ PVP or $5 \mathrm{mM}$ $\mathrm{AgNO}_{3}, 40 \mathrm{mM} \mathrm{Na}_{2} \mathrm{~S}_{2} \mathrm{O}_{3}$ and $0.1 \mathrm{mM} \mathrm{PVP}$, both at $25^{\circ} \mathrm{C}$ ) with different times of sonication. The resulting samples were submitted to SEM (Fig. 2 and Fig. S2). Although, under some conditions, an improvement in the homogeneity of the Ag nanoparticles distribution was observed, prolonged sonication time was found to cause also a significant decrease in the Ag 
loading, probably due to detachment and release of Ag nanoparticles. For this reason, no sonication was applied in further Ag deposition experiments.
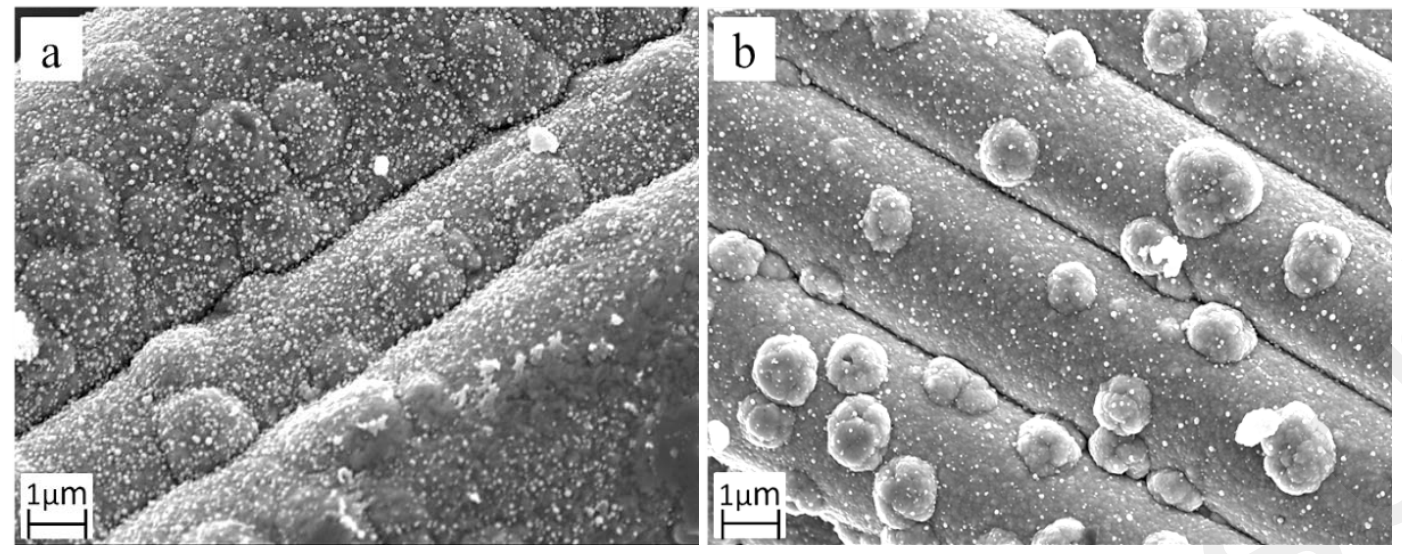

Fig. 2. SEM images of Ag-Ni-graphite felt samples prepared in $5 \mathrm{mM} \mathrm{AgNO}{ }_{3}, 40 \mathrm{mM}$ $\mathrm{Na}_{2} \mathrm{~S}_{2} \mathrm{O}_{3}$ and $0.2 \mathrm{mM}$ PVP, deposition time $15 \mathrm{~min}, 7.5 \mathrm{~min}$ with sonication at $25^{\circ} \mathrm{C}$. External: (a); internal: (b).

To improve the Ag nanoparticle loading on Ni@GF, the effects of $\mathrm{Ag}^{+}$concentration and deposition time were investigated. No significant difference in Ag nanoparticles distribution was observed between samples prepared in $10 \mathrm{mM} \mathrm{AgNO}_{3}, 80 \mathrm{mM} \mathrm{Na}_{2} \mathrm{~S}_{2} \mathrm{O}_{3}$, and $0.2 \mathrm{mM}$ PVP (Fig. S2 (c-d)) or in $5 \mathrm{mM} \mathrm{AgNO}_{3}, 40 \mathrm{mM} \mathrm{Na} \mathrm{S}_{2} \mathrm{O}_{3}$, and $0.1 \mathrm{mM}$ PVP (Fig. 2). Hence, lower reactant concentrations ( $1 \mathrm{mM} \mathrm{AgNO}_{3}, 8 \mathrm{mM} \mathrm{Na}_{2} \mathrm{~S}_{2} \mathrm{O}_{3}$ and $0.1 \mathrm{mM}$ PVP) were tested, but with longer deposition times (30, 45 or $60 \mathrm{~min})$ with magnetic stirring (500 rpm). SEM images of the samples, named Ag(30)/Ni@GF, Ag(45)/Ni@GF, and Ag(60)/Ni@GF for 30, 45 and 60min deposition times, respectively, are shown in Fig. 3. For all deposition times, uniform distributions of Ag nanoparticles were observed, with minor differences between the internal and external parts of the Ni@GF.Ag(30)/Ni@GF had a very low density of smallsized Ag nanoparticles. The Ag nanoparticles on Ag(45)/Ni@GFs were island-like, with a high density, whereas aggregation of nanoparticles occurred with Ag(60)/Ni@GF. 
Since the Ni thickness was only $0.19 \mu \mathrm{m}$, EDS analysis was able to quantify Ag and Ni on the surface of the carbon fibers and a reliable Ag/Ni ratio could be estimated (Table 1). A low Ag content was obtained after 30min deposition, which significantly increased after 45 and 60min of reaction, suggesting that there is a significant induction period during the initial phase of the deposition step. The average particle diameter was also estimated by analysis of the SEM images in Fig. 3 (Table 1). For the Ag(45)/Ni@GF sample, about half of Ag nanoparticles had diameters between 30 and 50 nm (Fig. S3). Ag(45)/Ni@GF electrodes were preferentially used in studies on the electrocatalytic activity (see below).

Table 1. Ag loading and average particle size of Ag nanoparticles on Ni@GF for different deposition times in $1 \mathrm{mM} \mathrm{AgNO}_{3}, 8 \mathrm{mM} \mathrm{Na}_{2} \mathrm{~S}_{2} \mathrm{O}_{3}$ and $0.1 \mathrm{mM}$ PVP.

\begin{tabular}{llll}
\hline \multirow{2}{*}{ Electrode } & \multicolumn{2}{l}{ Ag loading by SEM-EDS analysis } & \\
\cline { 2 - 3 } & Atomic $\%$ & Mass $\%$ & \\
\hline $\mathrm{Ag}(30) / \mathrm{Ni} @ G \mathrm{GF}$ & 0.9 & 1.6 & -- \\
$\mathrm{Ag}(45) / \mathrm{Ni} @ G F$ & 9.8 & 16.6 & $\sim 40$ \\
$\mathrm{Ag}(60) / \mathrm{Ni} @ G F$ & 22.1 & 33.6 & $\sim 100$ \\
\hline
\end{tabular}



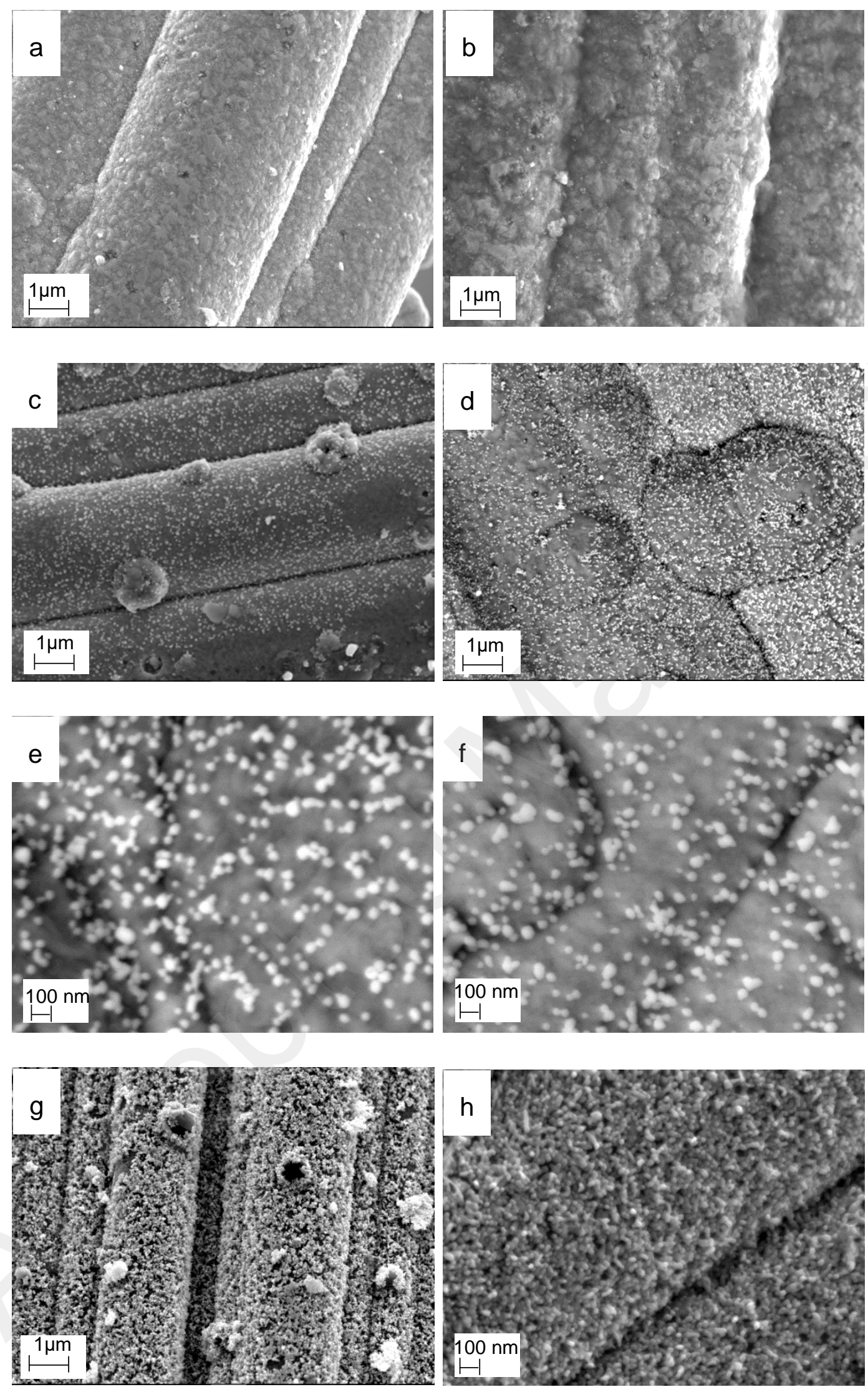
Fig. 3. SEM images of Ag/Ni@GF samples prepared in $1 \mathrm{mM} \mathrm{AgNO} 3,8 \mathrm{mM} \mathrm{Na}_{2} \mathrm{~S}_{2} \mathrm{O}_{3}$ and 0.1 mM PVP at 25ㄷ. Ag(30)/Ni@GF (a-b), Ag(45)/Ni@GF (c-f), and Ag(60)/Ni@GF (g-h). External: (a,c,e,g) and internal: (b,d,f,h).

\subsection{Characterization of Ag/Ni@GF}

The crystal structure and preferred orientation (texture) of Ag nanoparticles and Ni layers were studied by means of X-ray diffraction (XRD). Fig. 4 shows the X-ray diffractograms of Ag/Ni@GF, Ni@GF and GF. The diffraction peaks of Ag appear at $2 \theta=38.6^{\circ}, 64.5^{\circ}$, and $77.4^{\circ}$, which correspond to the (111), (220), and (311) planes, respectively. Peaks at $2 \theta=$ $44.6^{\circ}, 51.9^{\circ}$ and $76.4^{\circ}$, testify to the presence of metallic Ni on the GF [26-28]. Fig. 4 shows that the Ag nanoparticles have a predominant crystalline (111) facet [15], known for its strong catalytic activity [29]. Indeed, PVP is well known to control the shape and size of Ag nanoparticles during their formation. It has been reported [30] that PVP forms a strong bond with the (100) facets of Ag nanoparticles, lowering their free energies and growth rates, and resulting in favoring the formation of Ag (111) facets. The mean Ag crystallite size could be estimated to be around $17 \mathrm{~nm}$, calculated from the broadening $(\beta)$ of XRD peaks, according to the Scherrer relation, Equation (3):

$d=\frac{k \lambda}{\beta_{1 / 2} \cos (\theta)}$

where $d$ is the average crystallite size (nm), $\lambda$ the wavelength of X-ray radiation $(0.15406 \mathrm{~nm})$, $\theta$ is the angle at the position of the peak maximum, $\beta_{1 / 2}$ is the width of the diffraction peak at half height, and $k$ is 0.94 . 


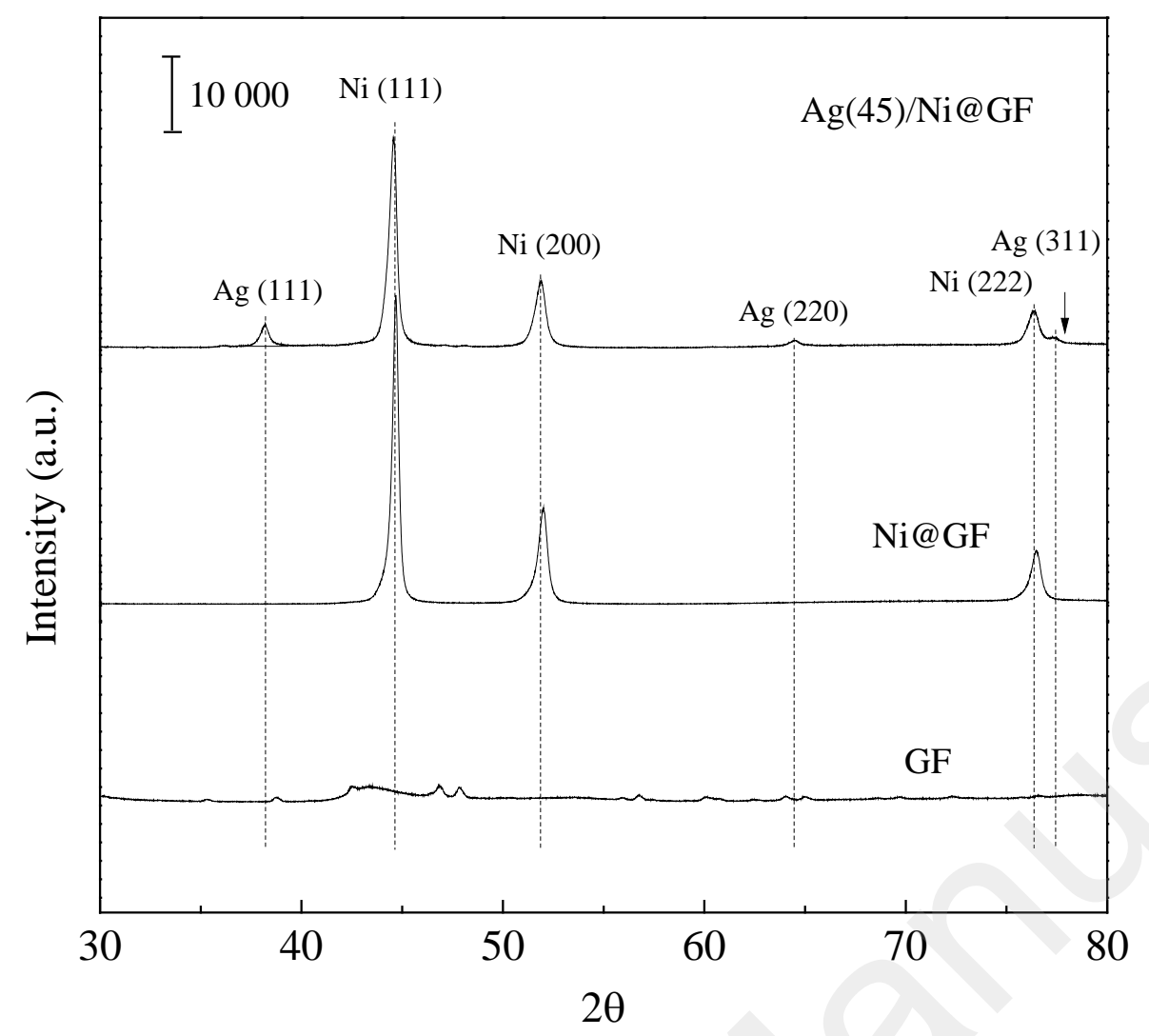

Fig. 4. XRD analysis of Ag(45)/Ni@GF, Ni@GF, and GF

The $17 \mathrm{~nm}$ crystallite dimension is significantly lower than the particle size estimated by SEM (Table 1). This suggests that most nanoparticles consisted of assemblies of tinier crystallites. It is also possible that the average crystallite size obtained by XRD was underestimated owing to the porosity and light weight of the graphite matrix responsible for a large penetration depth for X-rays, leading to a non-negligible peak broadening.

We have previously reported that, after the modified electrode is dissolved in a $5 \mathrm{M}$ solution of $\mathrm{HNO}_{3}$ at $80^{\circ} \mathrm{C}, \mathrm{Ag}$ loading could be estimated by linear sweep voltammetry at a gold rotating disc electrode $(2000 \mathrm{rpm})$. The concentration of $\mathrm{Ag}^{+}$ions determined with this method agreed within 5\% with results given by ICP-MS [17]. Using the same electrochemical method, we found a Ag loading in Ag(45)/Ni@GF of 13.7 $\pm 1.3 \mathrm{mg} \mathrm{cm}^{-3}$ (Table 2). RDE voltammograms and calibration curve for the determination of Ag loading are shown in Fig. 
S4. A comparison with the results previously obtained for Ag nanoparticle-modified Ni foams [17] highlighted that Ag loading was almost 7 times higher for Ag(45)/Ni@GF and that the average size of Ag nanoparticles (40 nm) was less than half.

Table 2. Characteristics of different Ag nanoparticle-modified porous electrodes

\begin{tabular}{|c|c|c|c|}
\hline Electrode & Ag loading $\left(\mathrm{mg} \mathrm{cm}^{-3}\right)$ & $\begin{array}{l}\text { Average nanoparticles } \\
\text { size (nm) }\end{array}$ & Reference \\
\hline Ag/Ni@GF & 13.7 (16.6 w.\%, 9.8 at\% ${ }^{\mathrm{C}}$ ) & $40^{\mathrm{a}}, 17^{\mathrm{b}}$ & This work \\
\hline $\mathrm{Ag} / \mathrm{Ni}$ foam ${ }^{\mathrm{d}}$ & 1.9 & Mostly below $100^{\mathrm{a}}$ & [17] \\
\hline Nano-Ag/carbon powder & $10 \mathrm{w} . \%^{\mathrm{d}}$ & $2-15^{\mathrm{a}}, 15-20^{\mathrm{b}}$ & [14] \\
\hline
\end{tabular}

${ }^{\mathrm{a}}$ Estimated from SEM analyses ${ }^{\mathrm{b}}$ Calculated from the Scherrer equation ${ }^{\mathrm{c}} \mathrm{Ag}$ loading in mass \% (w.\%) and atomic \% (at \%) determined by SEM-EDS. ${ }^{\mathrm{d}}$ Mass content controlled during electrode preparation.

To check whether PVP, necessary to achieve the desired morphology of Ag deposits, remained adsorbed on the nanoparticles surface, possibly influencing their catalytic activity, Ag(45)/Ni@GF was investigated by means of Surface-enhanced Raman spectroscopy (SERS). The black curve in Fig. 5 clearly shows the presence of PVP adsorbed on Ag nanoparticles, highlighted by characteristic peaks of the $\mathrm{N}-\mathrm{C}=\mathrm{O}$ ring deformation stretching at $690 \mathrm{~cm}^{-1}$ and of the $\mathrm{C}=\mathrm{O}$ stretching at $1764 \mathrm{~cm}^{-1}$ [31]. Broad peaks appearing around 1330 and $1580 \mathrm{~cm}^{-1}$ were due to amorphous carbon from the graphite felt support. The red curve, recorded for a Ag(45)/Ni@GF electrode after its use in an electrolysis, is discussed below. 


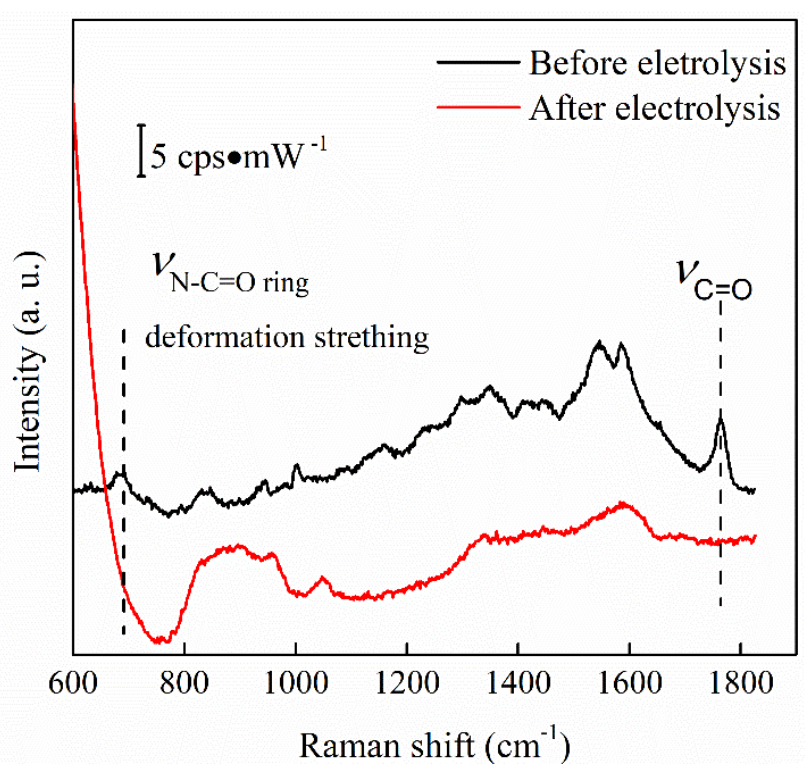

Fig. 5. SERS spectra recorded with as-prepared Ag/Ni@GF (black curve) and the same electrode after $100 \mathrm{~min}$ electrolysis in $0.05 \mathrm{M} \mathrm{NaOH}$ solution containing $50 \mathrm{mg} \mathrm{L}^{-1}$ alachlor (red curve). Both spectra are averaged results from at least 10 trials.

Owing to its importance in electrocatalysis, the electrode surface area was determined by BET measurements and by electroanalytical methods (Table 3). The BET surface area of Ni@GF was $19 \mathrm{~m}^{2} \mathrm{~g}^{-1}$ and increased to $26 \mathrm{~m}^{2} \mathrm{~g}^{-1}$ after modification with Ag nanoparticles. The area increase was probably caused by the additional Ag area and by the roughening of $\mathrm{Ni}$ due to the galvanic displacement reaction [32].

The specific surface area given by BET takes into account the surface of all the pores that nitrogen gas can penetrate. However, since organic molecules cannot penetrate into tiny pores, the electrochemically active surface area (EASA) was determined, to compare Ni@GF and Ni foam. Two electrochemical methods were used to measure the EASA: (i) cyclic voltammetry in $1 \mathrm{M} \mathrm{KOH}$, with measurement of the charge corresponding to the $\mathrm{Ni}(\mathrm{OH})_{2} / \mathrm{NiOOH}$ couple (Fig. S5) [17]; (ii) cyclic voltammetry in $1 \mathrm{mM} \mathrm{K}_{3}\left[\mathrm{Fe}(\mathrm{CN})_{6}\right]$ as a redox probe and application of the Randles-Sevcik equation for a one-electron process (Equation (4)) [33]: 
$I_{p}=0.446 F S C_{0} \sqrt{D_{0}} \sqrt{\frac{F}{R T}} \sqrt{\mathrm{V}}$

with $I_{p}$ peak current, $F$ Faraday constant, $S$ electrode surface, $D_{0}$ diffusion constant, $C_{0}$ concentration of $\mathrm{Fe}(\mathrm{CN})_{6}{ }^{3-}, R$ universal gas constant, $T$ absolute temperature and $v$ scan rate. In the latter method, the linear dependence of the oxidation peak current vs. scan rate allowed the estimation of the EASA of Ni foam and Ni@GF (Fig. S6) [33,34]. Measurements of the EASA of Ni@GF with the electrochemical methods gave results of the same order of magnitude, though significantly different, whereas the BET area was approximately 20 times higher than the EASA. BET area for Ni foam was not determined, so a comparison between Ni foam and Ni@GF was possible only on the basis of EASA. The ratio between the surface areas of Ni@GF and Ni foam depended on the method: it was ca. 2.8 (Randles-Sevcik equation) or ca. $12\left(\mathrm{Ni}(\mathrm{OH})_{2} / \mathrm{NiOOH}\right.$ redox couple). Since the typical Ag loading per unit volume was about 7 times higher on Ni@GF than on Ni foam (Table 2), the Ag loadings per unit EASA were comparable for both systems.

On the basis of data reported in Table 2 (Ag loading and average particle dimension), it is possible to estimate an approximate Ag surface area, by assuming the Ag nanoparticles to be spherical, all with the same diameter, identical to the average value. Under these assumptions, the Ag surface area per unit volume of the catalyst $\left(\mathrm{S}_{\mathrm{Ag}}\right)$ is given by:

$S_{A g}=\frac{6 L}{\rho d}$

where $L$ is the Ag loading, $\rho$ is its density and $d$ is the particle diameter. Calculations according to Equation (5) yield ca. $1960 \mathrm{~cm}^{2} \mathrm{~cm}^{-3}$ for Ag-modified Ni@GF and ca. $110 \mathrm{~cm}^{2}$ $\mathrm{cm}^{-3}$ for Ag-modified Ni foam. Thus, it may be concluded that, thanks to the larger surface area of the Ni@GF support, the smaller size of the Ag nanoparticles and the higher Ag loading per volume, Ag-modified Ni@GF had ca. 20 times larger Ag surface area than Ag- 
modified $\mathrm{Ni}$ foam, which was a favorable feature for its application as electrocatalyst. Another interesting feature of Ni@GF was its low density compared with Ni foam, owing to the presence of graphite inside the Ni fibers.

Table 3. Specific surface area and density of Ni@GF and Ni foam.

\begin{tabular}{lllll}
\hline \multirow{2}{*}{ Electrode } & \multicolumn{2}{l}{ Electrode surface } & \multirow{2}{*}{ Density $\left(\mathrm{mg} \mathrm{cm}^{-3}\right)$} \\
\cline { 2 - 4 } & \multirow{2}{*}{ BET area $\left(\mathrm{cm}^{2} \mathrm{~cm}^{-3}\right)$} & \multicolumn{2}{l}{ EASA $\left(\mathrm{cm}^{2} \mathrm{~cm}^{-3}\right)$} & \\
\cline { 2 - 4 } & & $\mathrm{K}_{3}\left[\mathrm{Fe}(\mathrm{CN})_{6}\right]$ & $\mathrm{Ni}\left(\mathrm{OH}_{2}\right) / \mathrm{NiOOH}$ & \\
\hline Ni@GF & $37240^{\mathrm{a}}$ & 1060 & 2780 & $196 \pm 4$ \\
Ni foam & - & 380 & $225^{\mathrm{b}}$ & $328 \pm 4$ \\
\hline
\end{tabular}

${ }^{\mathrm{a}}$ This BET area value expressed in $\mathrm{cm}^{2} \mathrm{~cm}^{-3}$ is calculated from the measured $19 \mathrm{~m}^{2} \mathrm{~g}^{-1}$ value.

${ }^{\mathrm{b}}$ In previous work [35], EASA of $235 \mathrm{~cm}^{2} \mathrm{~cm}^{-3}$ (before etching) and $285 \mathrm{~cm}^{2} \mathrm{~cm}^{-3}$ (after etching) was measured for a similar Ni foam.

\subsection{Dechlorination of alachlor ${ }^{T M}$}

Voltammograms obtained at a Ag disk in $0.05 \mathrm{M} \mathrm{NaOH}$, with and without $100 \mathrm{mg} \mathrm{L}^{-1}$ alachlor are compared in Fig. 6. A significant reduction peak at $-1.28 \mathrm{~V}_{\text {/MSE }}$, visible only in the presence of alachlor, shows the expected electrocatalytic activity of Ag towards dechlorination processes.

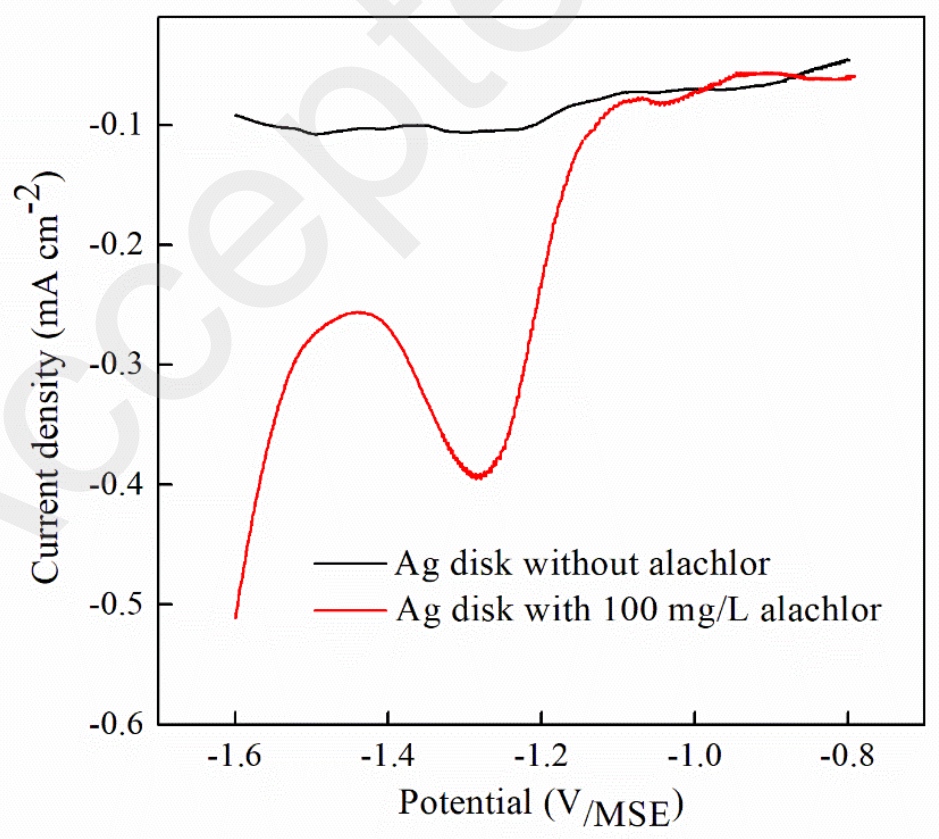


Fig. 6. Voltammograms recorded at $\mathrm{Ag}$ disk in $0.05 \mathrm{M} \mathrm{NaOH}$ solution with and without 100 $\mathrm{mg} \mathrm{L}^{-1}$ alachlor. Scan rate $100 \mathrm{mV} \mathrm{s}^{-1}$.

Bulk electrolyses for the reductive dechlorination of $50 \mathrm{mg} \mathrm{L}^{-1}$ alachlor in $0.05 \mathrm{M} \mathrm{NaOH}$ were performed in a flow electrochemical cell. Fig. 7 shows the alachlor conversion (a) and deschloroalachlor production (b) in six successive electrolyses carried out at $-1.6 \mathrm{~V} / \mathrm{MSE}$ with the same Ag(45)/Ni@GF and Ag(60)/Ni@GF working electrodes, used to compare the influence of the Ag loading. In the first electrolysis, alachlor conversions was slightly lower (95.0\% vs. 98.3\%) and the selectivity for deschloroalachlor production was slightly higher (70.2\% vs. 66.1\%) on Ag(45)/Ni@GF than on Ag(60)/Ni@GF. Thus, the Ag loading, twice higher for Ag(60)/Ni@GF than for Ag(45)/Ni@GF, had a minor influence on the catalytic activity. Results obtained with both Ag-modified Ni@GF electrodes were significantly better than those previously found, under the same conditions, with Ag-Ni foam electrode (51.0\% alachlor conversion with 36.4\% deschloroalachlor production, after 60min electrolysis [17]). Higher Ag loadings and larger EASA, resulting in larger Ag surface areas, were probable causes of the better catalytic activity of Ag-modified Ni@GF.

As shown in Fig. 7, during successive electrolyses, alachlor conversion became higher for Ag(45)/Ni@GF than for Ag(60)/Ni@GF and the selectivity for deschloroalachlor remained higher for the former, with a progressively larger difference. A 5.1\% decrease in alachlor conversion and 9.7\% decrease in descholoralachlor production, after 6 electrolyses, showed the significantly better stability of Ag(45)/Ni@GF, compared to Ag(60)/Ni@GF (ca. 17\% decrease in both alachlor conversion and deschloroalachlor production). 

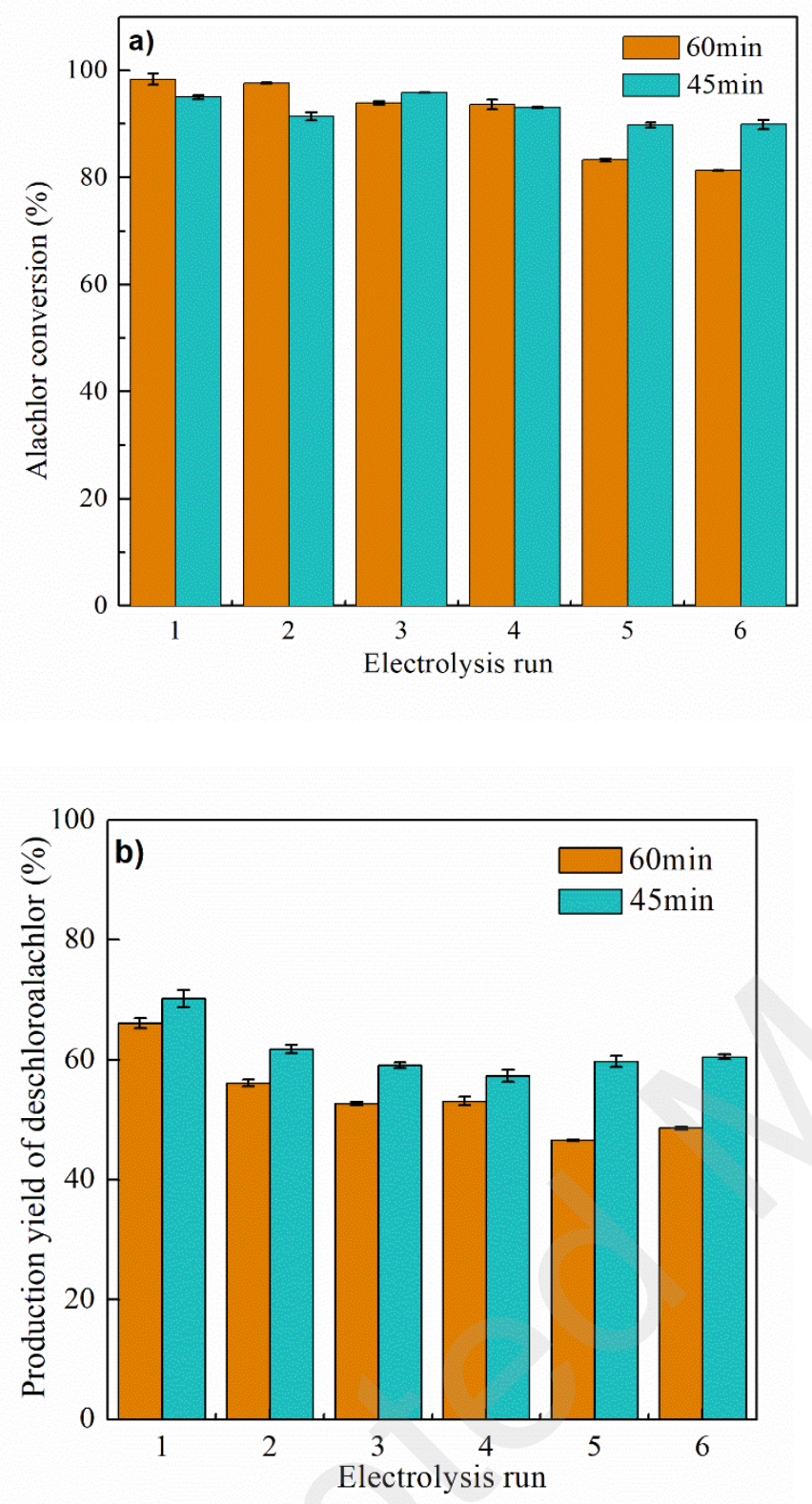

Fig. 7. Effect of Ag loading on the conversion of alachlor (a) and production of deschloroalachlor (b). Electrolyses were performed at -1.6 V/MSE on Ag(45)/Ni@GF and Ag(60)/Ni@GF, in $0.05 \mathrm{M} \mathrm{NaOH}$ containing $50 \mathrm{mg} \mathrm{L}^{-1}$ alachlor, for 100min. Error bars are based on two HPLC analyses.

The morphology of Ag(45)/Ni@GF and Ag(60)/Ni@GF electrodes before and after 6 electrolyses was compared by SEM (Fig. 8).Ag(45)/Ni@GF exhibited no obvious changes of 
both Ni layer and island-like Ag nanoparticles. Ag(60)/Ni@GF showed some areas with exfoliation of the Ni layer and, unavoidably, loss of the Ag nanoparticles present on it, which can explain the observed loss of catalytic activity. In the case of $\mathrm{Ag}(60) / \mathrm{Ni} @ \mathrm{GF}$, the more extensive deposition of Ag certainly caused a higher consumption of $\mathrm{Ni}$, and possibly a stronger strain of the residual Ni layer, rendering it more fragile towards the stress caused by hydrogen evolution that cannot be avoided at the applied potential of -1.6 V/MSE [20].

A Ag(45)/Ni@GF electrode used in a 100min electrolysis was characterized again with the aid of SERS. The red curve in Fig. 5 shows the disappearance of characteristic peaks of PVP after the electrolysis, indicating that the electroreduction led to complete desorption of PVP from the Ag nanoparticles. Since the Ag(45)/Ni@GF electrode retained the same level of electrocatalytic activity during several electrolyses, one can conclude that the initially adsorbed PVP had neither positive nor negative influence on the dechlorination reaction. 

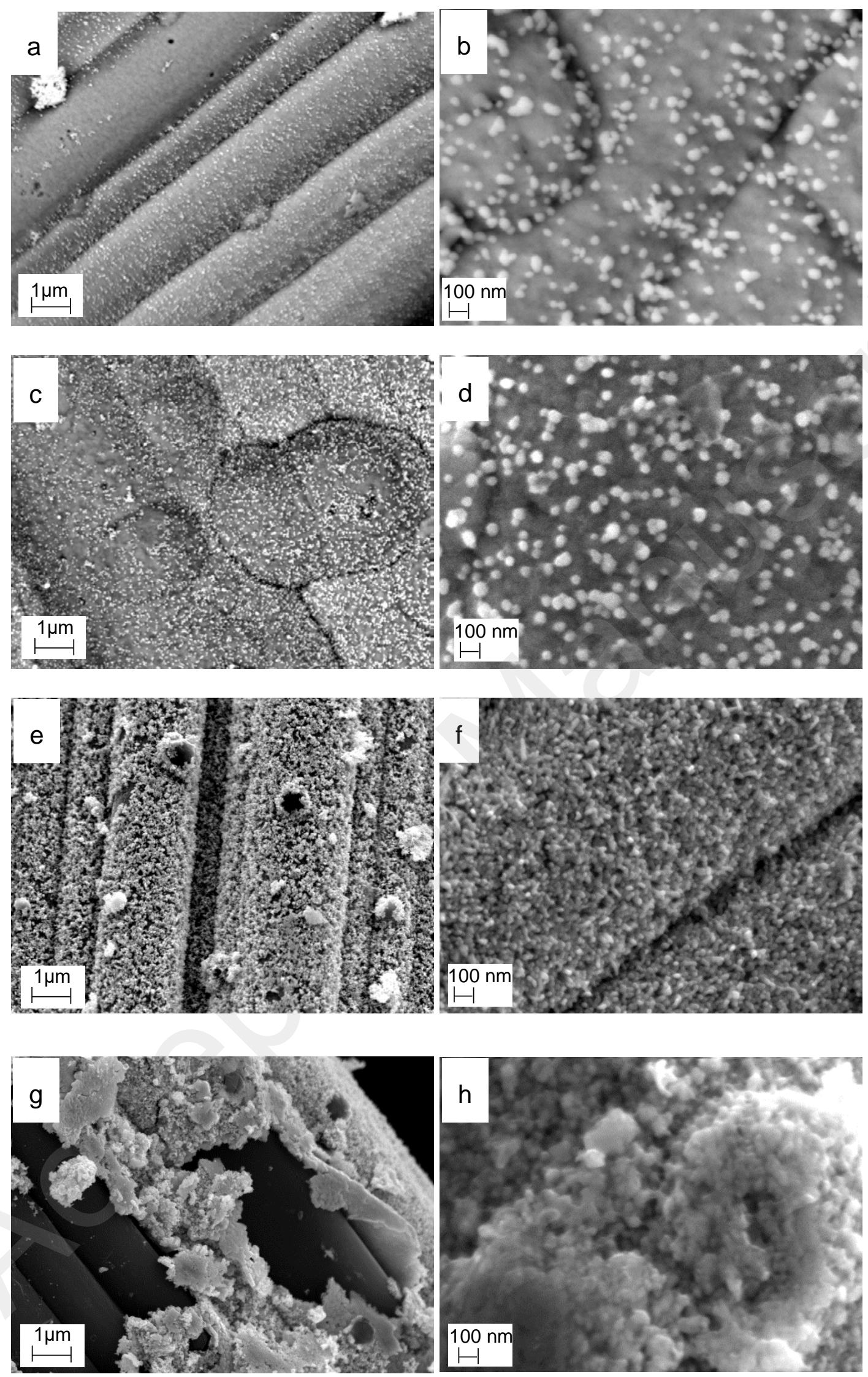
Fig. 8. SEM analysis of Ag(45)/Ni@GF (a-d) and Ag(60)/Ni@GF (e-h) before (a-b,e-f) and after (c-d, g-h) 6 electrolyses.

To improve the current efficiency, a less negative potential was applied to favor the reduction of alachlor and to decrease hydrogen evolution. Fig. 9 shows the effect of the applied potential on the reductive dechlorination of $50 \mathrm{mg} \mathrm{L}^{-1}$ alachlor, performed in $0.05 \mathrm{M} \mathrm{NaOH}$ at -0.9 and -1.6 V/MSE on Ag(45)/Ni@GF, and compared with results obtained with an unmodified Ni@GF electrode. As previously observed [35], Ni@GF could reduce alachlor, but with slower kinetics and much lower selectivity for deschloroalachlor. It is worth noting that, for the three-dimensional electrode, a potential distribution occurs opposite to a planar electrode, explaining that at $-0.9 \mathrm{~V}$ the electroreduction of alachlor already happened, whereas no current was observed on the voltammogram of Fig. 7. Table 4 shows the effect of applied potential and $\mathrm{NaOH}$ concentration on the current efficiency, in addition to the data on alachlor conversion and deschloroalachlor formation, after a 100min electrolysis. When the potential was decreased from -1.6 to -0.9 $\mathrm{V}_{\text {/MSE}}$, the current efficiency for Ag(45)/Ni@GF increased from $0.8 \%$ to $36.6 \%$, whereas a similar conversion of alachlor and the yield of deschloroalachlor were maintained. The increase of the $\mathrm{pH}(0.1 \mathrm{M} \mathrm{NaOH}$ solution) also slightly increased the current efficiency, due to the less strong competition by the hydrogen evolution reaction, and both alachlor conversion and deschloroalachlor production slightly increased. 
Table 4. Influence of applied potential and $\mathrm{NaOH}$ concentration on alachlor conversion, deschloroalachlor production, and current efficiencies in 100min electrolyses.

\begin{tabular}{llllll}
\hline Electrode & $\begin{array}{l}\text { Potential } \\
\left(\mathrm{V}_{\text {/MSE }}\right)\end{array}$ & $\begin{array}{l}\mathrm{NaOH} \\
\text { concentration } \\
(\mathrm{M})\end{array}$ & $\begin{array}{l}\text { Current } \\
\text { efficiency } \\
(\%)\end{array}$ & $\begin{array}{l}\text { Removal of } \\
\text { alachlor } \\
(\%)\end{array}$ & $\begin{array}{l}\text { Production of } \\
\text { deschloroalachlor } \\
(\%)\end{array}$ \\
\hline Ni@GF & -1.6 & 0.05 & $0.4 \pm 0.05$ & 82.8 & 39.3 \\
Ag/Ni@GF & -0.9 & 0.05 & $36.6 \pm 2$ & 96.0 & 76.1 \\
& -1.6 & 0.05 & $0.8 \pm 0.08$ & 93.8 & 71.6 \\
& -1.6 & 0.1 & $3.7 \pm 0.8$ & 99.0 & 74.1 \\
\hline
\end{tabular}

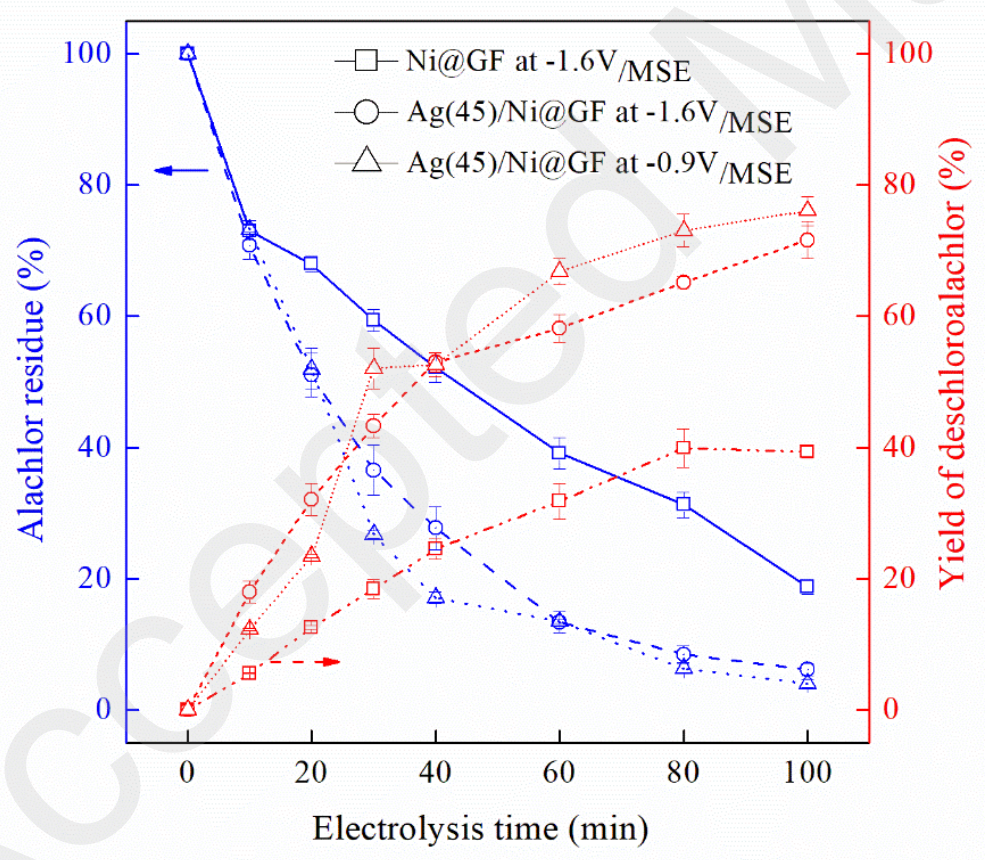

Fig. 9. Effect of cathode potential on the electrochemical conversion efficiency of alachlor (in blue) and yield of deschloroalachlor (in orange) performed at -0.9 and -1.6 V/MSE on Ni@GF and Ag(45)/Ni@GF, in 0.05 M NaOH containing $50 \mathrm{mg} \mathrm{L}^{-1}$ alachlor for 100min electrolysis. 


\section{Conclusions}

NewAg/Ni@GF electrodes for the dechlorination of organic chlorides have been prepared by modifying Ni-coated graphite felts with Ag nanoparticles. These particles were deposited through a galvanic displacement reaction that would be easy to scale up for the preparation of large-size electrodes for environmental applications, at moderate cost. The experimental conditions previously reported to modify $\mathrm{Ni}$ foam with Ag nanoparticles [18] had to be adapted to Ni@GF, owing to its high surface area. Whereas the increase of mass transport by sonication did not allow a homogenous repartition of nanoparticles, an increase of $\mathrm{Ag}^{+}$ concentration and of deposition time led to uniform distributions of Ag nanoparticles inside the Ni@GF. PVP was required as capping agent to control the shape and the size of Ag nanoparticles, leading to main crystal facets [111]. SERS experiments showed that PVP is adsorbed on Ag particles on Ag/Ni@GF electrodes, but is totally desorbed during electroreduction.

Interestingly, Ag/Ni@GF electrodes had high Ag loading (13.7 mg cm²), high specific surface area $\left(26 \mathrm{~m}^{2} \mathrm{~g}^{-1}\right)$ and low density, since graphite felt was used as support. The Ag surface area in these electrodes could be estimated, from Ag loading and nanoparticles average dimension, to be close to $2000 \mathrm{~cm}^{2} \mathrm{~cm}^{-3}$, which is 20 times larger than those of $\mathrm{Ag}$ nanoparticle-modified nickel foam.

Due to its interesting properties, Ag/Ni@GF electrodes exhibit good catalytic activity in the dechlorination of alachlor, with high conversion yields of 96-99\% and current efficiency up to 36.6\%. Good selectivity was also achieved, with the formation of $76.1 \%$ deschloroalachlor. Furthermore, the Ag/Ni@GF electrode displayed good stability after 6 successive electrolyses. 


\section{Acknowledgements}

The authors thank the China Scholarship Council for a Ph.D. grant. We also thank our joint laboratory, LIA CNRS NanoBioCatEchem, for supporting the collaboration with Xiamen University.

\section{Author Contributions:}

† Y.Y. Lou and W.Y. He contributed equally to this work.

\section{Supporting material}

Figures S1 to S6 and Tables S1, S2

\section{References}

[1] R.R. Solis, F.J. Rivas, O. Gimeno, J.L. Perez-Bote, J. Chem. Technol. Biotechnol., 92 (2017) 2159-2170.

[2] H. Chen, Z. Zhang, Z. Yang, Q. Yang, B. Li, Z. Bai, Chem. Eng. J., 273 (2015) 481-489.

[3] F.L. Souza, C. Saéz, M.R.V. Lanza, P. Cañizares, M.A. Rodrigo, Sep. Purif. Technol., 149 (2015) 24-30.

[4] O. Scialdone, A. Galia, L. Gurreri, S. Randazzo, Electrochim. Acta, 55 (2010) 701-708.

[5] A. Brzózka, A. Jeleń, A.M. Brudzisz, M.M. Marzec, G.D. Sulka, Electrochim. Acta, 225 (2017) 574-583.

[6] Y.H. Xu, Q.Q. Cai, H.X. Ma, Y. He, H. Zhang, C.A. Ma, Electrochim. Acta, 96 (2013) 90-96.

[7] P. Poizot, L. Laffont-Dantras, J. Simonet, J. Electroanal. Chem., 622 (2008) 204-210.

[8] M.O. Schmitt, S. Schneider, PhysChemComm, 3 (2000) 42-55. 
[9] F. Pagnanelli, P. Altimari, M. Bellagamba, G. Granata, E. Moscardini, P.G. Schiavi, L. Toro, Electrochim. Acta, 155 (2015) 228-235.

[10] J. Simonet, P. Poizot, L. Laffont, J. Electroanal. Chem., 591 (2006) 19-26.

[11] J. Simonet, V. Jouikov, Electrochem. Commun., 40 (2014) 58-62.

[12] Z. He, Q. Jian, J. Tang, T. Xu, J. Xu, Z. Yu, J. Chen, S. Song, Electrochim. Acta, 222 (2016) 488-498.

[13] M.D. Esclapez, M.I. Díez-García, V. Sáez, I. Tudela, J.M. Pérez, J. González-García, P. Bonete, Electrochim. Acta, 56 (2011) 8138-8146.

[14] S. Rondinini, G. Aricci, Ž. Krpetić, C. Locatelli, A. Minguzzi, F. Porta, A. Vertova, Fuel Cells, 9 (2009) 253-263.

[15] V. Bansal, V. Li, A.P. O'Mullane, S.K. Bhargava, CrystEngComm, 12 (2010) 4280-4286.

[16] M. Musiani, S. Cattarin, S. Cimino, N. Comisso, L. Mattarozzi, L. Vázquez-Gómez, E. Verlato, J. Appl. Electrochem., 45 (2015) 715-725.

[17] E. Verlato, W. He, A. Amrane, S. Barison, D. Floner, F. Fourcade, F. Geneste, M. Musiani, R. Seraglia, ChemElectroChem, 3 (2016) 2084-2092.

[18] Z. Peng, Z. Yu, L. Wang, Y. Hou, Y. Shi, L. Wu, Z. Li, Mater. Lett., 166 (2016) 300-303.

[19] D. Cao, Y. Gao, G. Wang, R. Miao, Y. Liu, Int. J. Hydrogen Energy, 35 (2010) 807-813.

[20] D. Floner, F. Geneste, Electrochem. Commun., 9 (2007) 2271-2275.

[21] B. Liu, C. Ding, B. Xiao, L. Cui, M. Wang, Mater. Sci. Eng. C., 37 (2014) 108-112.

[22] J.-M. Fontmorin, W. He, D. Floner, F. Fourcade, A. Amrane, F. Geneste, Electrochim. Acta, 137 (2014) 511-517.

[23] B. Sanderson, J. Chem. Technol. Biotechnol., 79 (2004) 207-208.

[24] Y. Lu, S. Jiang, Y. Huang, Surf. Coat. Technol., 204 (2010) 2829-2833.

[25] B. Macijauskienè, E. Griškonis, Chemija, 26 (2015) 1-8.

[26] D.-H. Chen, S.-R. Wang, Mater. Chem. Phys., 100 (2006) 468-471.

[27] J. Simonet, Electrochem. Commun., 10 (2008) 647-650.

[28] S. Coskun, B. Aksoy, H.E. Unalan, Cryst. Growth Des., 11 (2011) 4963-4969. 
[29] S. Ardizzone, G. Cappelletti, L.M. Doubova, P.R. Mussini, S.M. Passeri, S. Rondinini, Electrochimica acta, 48 (2003) 3789-3796.

[30] Y. Xia, Y. Xiong, B. Lim, S.E. Skrabalak, Angew. Chem. Int. Ed., 48 (2009) 60-103.

[31] X. Xia, J. Zeng, L.K. Oetjen, Q. Li, Y. Xia, J. Am. Chem. Soc., 134 (2012) 1793-1801.

[32] E. Verlato, S. Cattarin, N. Comisso, A. Gambirasi, M. Musiani, L. Vázquez-Gómez, Electrocatalysis, 3 (2012) 48-58.

[33] A.J. Bard, L.R. Faulkner, Electrochemical Methods: Fundamentals and Applications, John Wiley \& Sons, Inc.2001.

[34] A.A. Ensafi, M. Jafari-Asl, B. Rezaei, PCCP, 17 (2015) 23770-23782.

[35] W. He, Y. Lou, E. Verlato, I. Soutrel, D. Floner, F. Fourcade, A. Amrane, M. Musiani, F. Geneste, J. Chem. Technol. Biotechnol., 93 (2018) 1572-1578 